\title{
Efficacy of Some Post-emergence Herbicides and their Mixtures Against Complex Weed Flora in Wheat
}

\author{
Ratilal K. Mathukia*, Bhimjibhai K. Sagarka, Dhirubhai M. Panara and Bhagirathsinh S. Gohil
}

Dept. of Agronomy, College of Agriculture, Junagadh Agricultural University, Junagadh,Gujarat (362 001), India

\section{Corresponding Author}

Ratilal K. Mathukia

e-mail: rkmathukia@jau.in

\author{
Article History \\ Article ID: IJEP0230 \\ Received in $28^{\text {th }}$ October, 2017 \\ Received in revised form $2^{\text {nd }}$ February, 2018 \\ Accepted in final form $10^{\text {th }}$ February, 2018
}

\begin{abstract}
A field experiment was conducted during rabi season of 2015-16 at Junagadh (Gujarat) to evaluate efficacy of some post-emergence herbicides (metsulfuron, isoproturon, clodinafop, fenoxaprop) and their mixtures (sulfosulfuron+metsulfuron, clodinafop+metsulfuron, isoproturon+metsulfuron, isoproturon+fenoxaprop, isoproturon+clodinafop) against complex weed flora in wheat. The dominant weed flora noticed in the experimental field were Echinochloa colona, Cynodon dactylon, Brachiaria spp. and Dactyloctenium aegyptium among the monocots; Amaranthus viridis, Chenopodium album, Digera arvensis, Melilotus indica, Portulaca oleracea, Convolvulus arvensis, Euphorbia hirta and Phyllanthus niruri among the dicot weeds and Cyperus rotundus as sedge weed. The results revealed that hand weeding (HW) at 15 and $30 \mathrm{DAS}, \mathrm{HW}$ at $15 \mathrm{DAS} f b$ pre-mix sulfosulfuron+metsulfuron $\left(25 \mathrm{~g} \mathrm{ha}^{-1}\right)$ at $30 \mathrm{DAS}$, and HW at $15 \mathrm{DAS} f b$ pre-mix clodinafop+metsulfuron $\left(32 \mathrm{~g} \mathrm{ha}^{-1}\right)$ at 30 DAS were found superior treatments next to the weed free check in controlling weeds and improving growth and yield attributes and ultimately grain and straw yields of wheat. It is suggested that pre-mix sulfosulfuron + metsulfuron or clodinafop+metsulfuron could be used to control broad spectrum of weeds in wheat. The herbicide mix could be helpful in reducing herbicide residue in soil and prevent or delay the development of herbicide resistance weeds.
\end{abstract}

Keywords: Post-emergence, herbicides mixture, weeds, wheat, sulfosulfuron, metsulfuron, clodinafop

\section{Introduction}

Wheat is infested by multifarious weed flora comprising both grassy as well as broad-leaved weeds causing yield reduction of $15-40 \%$ depending upon type and intensity of their infestation (Katara et al., 2012; Singh et al., 2012; Kumar et al., 2013). Weed competition is intense during first 30-40 days after sowing the wheat crop. Herbicides continue to be the most powerful, economically effective and reliable way to control weeds in wheat. Pendimethalin $900 \mathrm{~g} \mathrm{ha}^{-1}$ as pre-emergence is effective to control grasses and broadleaved weeds. Post-emergent herbicides viz., 2,4-D and metsulfuron are recommended for effective weed control in wheat, but residues of these herbicides in soil restrict choice of succeeding crops. Thus, it became important to evaluate new herbicide molecules for management of weeds in wheat. Since, no single herbicide controls both narrow and broad-leaved weeds, therefore, mixing of herbicideshave shown great promise in controlling complex weed flora of wheat. Several new herbicides viz., clodinafop, fenoxaprop, sulfosulfuron, carfentrazone, diclofop, pinoxaden and premix sulfosulfuron+metsulfuron, clodinafop+metsulfuron, carfentrazone+sulfosulfuron, clodinafop+metribuzin, fenoxaprop+metribuzin and metsulfuron+carfentrazone have been found very effective in controlling weeds without any residual effect on succeeding crops as well as to prevent development of herbicide resistant weeds in wheat (Chopra et al., 2015; Sharma et al., 2015; Pal et al., 2015).

\section{Materials and Methods}

A field experiment was conducted at Weed Control Research Farm, Department of Agronomy, College of Agriculture, Junagadh Agricultural University, Junagadh (Gujarat) during Rabi season of 2015-16. The soil of the experimental plot was clayey in texture and slightly alkaline in reaction as well as low in available nitrogen, available phosphorus and medium in available potash. The experiment comprising of 12 treatments viz., $\mathrm{T}_{1}$ : HW at 15 DAS $f b$ metsulfuron $4 \mathrm{~g} \mathrm{ha}^{-1}$ at $30 \mathrm{DAS}, \mathrm{T}_{2}$ : $\mathrm{HW}$ at 15 DAS $f b$ isoproturon $500 \mathrm{~g} \mathrm{ha}^{-1}$ at $30 \mathrm{DAS}, \mathrm{T}_{3}$ : HW at 15 DAS $f b$ clodinafop $60 \mathrm{~g} \mathrm{ha}^{-1}$ at 30 DAS, $\mathrm{T}_{4}$ : HW at 15 DAS $f b$ fenoxaprop $90 \mathrm{~g} \mathrm{ha}^{-1}$ at $30 \mathrm{DAS}, \mathrm{T}_{5}$ : HW at 15 DAS $f b$ pre-mix sulfosulfuron+metsulfuron $25 \mathrm{~g} \mathrm{ha}^{-1}$ at $30 \mathrm{DAS}, \mathrm{T}_{6}: \mathrm{HW}$ at 15 DAS $f b$ pre-mix clodinafop+metsulfuron $32 \mathrm{~g} \mathrm{ha}^{-1}$ at $30 \mathrm{DAS}, \mathrm{T}_{7}$ : $\mathrm{HW}$ at 15 DAS $f b$ tank-mix isoproturon $250 \mathrm{~g} \mathrm{ha}^{-1}+$ metsulfuron $2 \mathrm{~g} \mathrm{ha}^{-1}$ at $30 \mathrm{DAS}, \mathrm{T}_{8}$ : HW at 15 DAS $\mathrm{fb}$ tank-mix isoproturon $250 \mathrm{~g} \mathrm{ha}^{-1}+$ fenoxaprop $45 \mathrm{~g} \mathrm{ha}^{-1}$ at $30 \mathrm{DAS}, \mathrm{T}_{9}$ : HW at 15 DAS 
$\mathrm{fb}$ tank-mix isoproturon $250 \mathrm{~g} \mathrm{ha}^{-1}+$ clodinafop $30 \mathrm{~g} \mathrm{ha}^{-1}$ at 30 DAS, $T_{10}$ : HW at 15 and 30 DAS, $T_{11}$ : Weed-free check, and $T_{12}$ : Weedy check was laid out in randomized block design with three replications. The gross and net plot size were 5.0x2.7 $\mathrm{m}^{2}$ and $4.0 \times 1.8 \mathrm{~m}^{2}$, respectively. The wheat variety ' $\mathrm{GW}-366$ ' was sown by tractor operated automatic seed drill at row spacing of $22.5 \mathrm{~cm}$ using seed rate of $120 \mathrm{~kg} \mathrm{ha}^{-1}$. A fertilizer dose of $60-60-60 \mathrm{~kg} \mathrm{~N}-\mathrm{P}_{2} \mathrm{O}_{5}-\mathrm{K}_{2} \mathrm{O}$ ha-1 through Ammonium sulphate, Diammonium phosphate and Muriate of potash was applied before sowing as basal. Top dressing of $60 \mathrm{~kg} \mathrm{~N} \mathrm{ha}^{-1}$ in form of Urea was applied at 25 days after sowing. The postemergence spray was done at 30 DAS using knapsack sprayer with flood jet nozzle. The spray volume herbicide application was $500 \mathrm{~L} \mathrm{ha}^{-1}$. The crop was raised as per the recommended package of practices. Growth and yield attributing characters viz., plant height, no. of effective tillers $\mathrm{m}^{-1}$ row length, no. of spikelets spike ${ }^{-1}$, no. of grains spike ${ }^{-1}$ and 100 -seed weight were recorded at harvest. The crop was harvested from net plot at maturity. The grains were separated from plants by thresher and grain and straw yields were recorded for each plot. Dry weight of weeds was recorded at harvest. Weed index (WI) and weed control efficiency (WCE) were worked out using following formulae suggested by Gill and Kumar (1969); Kondap and Upadhyay (1985).
$W I=\frac{Y_{W F}-Y_{T}}{Y_{W F}} \times 100$

Where; $Y_{W F}$ and $Y_{T}$ are the yield from weed-free plot and yield from treated plot, respectively.

WCE $(\%)=\frac{D W_{c}-D_{T}}{D W_{c}} \times 100$

Where; $\mathrm{DW}_{\mathrm{c}}=$ Dry matter accumulation of weeds in unweeded control, $\mathrm{DW}_{\mathrm{T}}=$ Dry matter accumulation of weeds in treated plot.

\section{Results and Discussion}

The major weed flora noticed were Echinochloa colona, Cynodon dactylon, Brachiaria spp. and Dactyloctenium aegyptium among the monocots; Amaranthus viridis, Chenopodium album, Digera arvensis, Melilotus indica, Portulaca oleracea, Convolvulus arvensis, Euphorbia hirta and Phyllanthus niruri among the dicot weeds and Cyperus rotundus as sedge weed.

\subsection{Effect on crop}

Data presented in Table 1 showed growth and yield attributes viz., highest plant height, effective tillers $\mathrm{m}^{-1}$ row length, spikelets spike ${ }^{-1}$, grains spike ${ }^{-1}$ and 100 -seed weight were

\begin{tabular}{|c|c|c|c|c|c|}
\hline Treatment & $\begin{array}{l}\text { Plant height } \\
(\mathrm{cm})\end{array}$ & $\begin{array}{l}\text { Effective tillers/m } \\
\text { row length }\end{array}$ & $\begin{array}{l}\text { Spikelets } \\
\text { spike }^{-1}\end{array}$ & $\begin{array}{l}\text { Grains } \\
\text { spike }^{-1}\end{array}$ & $\begin{array}{l}100 \text {-seed } \\
\text { weight }(\mathrm{g})\end{array}$ \\
\hline HW $f b$ metsulfuron & 81.92 & 61.83 & 12.02 & 27.38 & 42.76 \\
\hline HW fb isoproturon & 81.53 & 60.33 & 11.82 & 26.93 & 42.48 \\
\hline HW fb clodinafop & 80.03 & 57.42 & 11.04 & 25.83 & 41.43 \\
\hline HW $f b$ fenoxaprop & 77.78 & 54.42 & 10.41 & 24.90 & 40.47 \\
\hline HW $f b$ sulfosulfuron+metsulfuron & 86.33 & 70.33 & 13.74 & 28.86 & 44.28 \\
\hline HW $f b$ clodinafop+metsulfuron & 85.17 & 68.58 & 13.03 & 28.11 & 43.89 \\
\hline $\mathrm{HW} f b$ isoproturon+metsulfuron & 82.97 & 63.25 & 12.34 & 27.82 & 43.65 \\
\hline HW $f b$ isoproturon+fenoxaprop & 79.43 & 55.83 & 10.48 & 25.47 & 41.07 \\
\hline HW $f b$ isoproturon+clodinafop & 80.97 & 59.38 & 11.21 & 26.66 & 41.88 \\
\hline HW twice & 88.06 & 71.32 & 13.86 & 29.24 & 44.47 \\
\hline Weed-free check & 89.17 & 72.73 & 14.52 & 29.41 & 44.73 \\
\hline Weedy check & 70.53 & 51.77 & 9.11 & 21.18 & 37.16 \\
\hline SEm \pm & 1.61 & 1.46 & 0.51 & 0.78 & 0.52 \\
\hline $\mathrm{CD}(p=0.05)$ & 4.73 & 4.307 & 1.50 & 2.30 & 1.53 \\
\hline
\end{tabular}

significantly influenced by different treatments.

Significantly the highest plant height $(89.17 \mathrm{~cm})$ was recorded under the weed-free check, however it remained statistically at par with $\mathrm{HW}$ at 15 and $30 \mathrm{DAS}(88.06 \mathrm{~cm}), \mathrm{HW}$ at $15 \mathrm{DAS} \mathrm{fb}$ pre-mix sulfosulfuron + metsulfuron $25 \mathrm{~g} \mathrm{ha}^{-1}$ at 30 DAS $(86.33$ $\mathrm{cm}$ ) and HW at 15 DAS $\mathrm{fb}$ pre-mix clodinafop+metsulfuron $\mathrm{g}$ $\mathrm{ha}^{-1}$ at 30 DAS $(85.17 \mathrm{~cm})$. Whereas, significantly the lowest plant height $(70.53 \mathrm{~cm})$ was registered under the weedy check. The weed free plot has significantly the highest number of effective tillers $\mathrm{m}^{-1}$ row length (72.73), however it remained statistically comparable to $\mathrm{HW}$ at 15 and 30 DAS (71.32), $\mathrm{HW}$ at 15 DAS $\mathrm{fb}$ pre-mix sulfosulfuron+metsulfuron 25 
$\mathrm{g} \mathrm{ha}^{-1}$ at 30 DAS (70.33) and HW at 15 DAS fb pre-mix clodinafop+metsulfuron $32 \mathrm{~g} \mathrm{ha}^{-1}$ at 30 DAS (68.58). The weedy check has significantly the lowest number of effective tillers $\mathrm{m}^{-1}$ row length (51.77).

Effective control of weeds through manual weeding in the weed free andHW at 15 and 30 DAS as well as combination of manual weeding with herbicide mix in under the treatments $\mathrm{HW}$ at 15 DAS $f b$ pre-mix sulfosulfuron+metsulfuron $25 \mathrm{~g} \mathrm{ha}^{-1}$ at $30 \mathrm{DAS}$, and $\mathrm{HW}$ at $15 \mathrm{DAS} f b$ pre-mix clodinafop+metsulfuron $32 \mathrm{~g} \mathrm{ha}^{-1}$ at 30 DAS caused less crop-weed competition throughout growth period of the crop, less count and dry weight of weeds, which might have resulted in better availability of space, sunlight, moisture and nutrients to the crop in absence of weeds. Thus, increased water and nutrient uptake, which might have accelerated photosynthetic rate, thereby increasing the supply of carbohydrates, resulted in cell division, multiplication and elongation leading to increase in growth character. These results were in conformity with Katara et al. (2012); Pisal and Sagarka (2013); Singh et al. (2013).

Number of spikelets spike ${ }^{-1}$ was significantly the highest (14.52) under the weed free treatment, but it was found statistically equivalent to $\mathrm{HW}$ at 15 and 30 DAS (13.86), HW at 15 DAS $f b$ pre-mix sulfosulfuron+metsulfuron $25 \mathrm{~g} \mathrm{ha}^{-1}$ at 30 DAS (13.74) and HW at 15 DAS fb pre-mix clodinafop + metsulfuron $32 \mathrm{~g} \mathrm{ha}^{-1}$ at 30 DAS (13.03). Obviously, the weedy check registered significantly the lowest number of spikelets spike $^{-1}$ (9.11).

Significantly the highest number of grains spike ${ }^{-1}$ (29.41) was observed under the weed free plot, however it did not differ significantly from HW at 15 and 30 DAS (29.24), HW at 15 DAS $f b$ pre-mix sulfosulfuron+metsulfuron $25 \mathrm{~g} \mathrm{ha}^{-1}$ at 30 DAS
(28.86) and HW at 15 DAS $f b$ pre-mix clodinafop+metsulfuron $32 \mathrm{~g} \mathrm{ha}^{-1}$ at 30 DAS (28.11). Evidently, the weedy check recorded significantly the lowest no. of grains spike ${ }^{-1}$ (9.11).

The weed free treatment recorded significantly the highest test weight (44.73 g), which remained statistically at par with $\mathrm{HW}$ at 15 and 30 DAS (44.47 g), HW at 15 DAS $f b$ pre-mix sulfosulfuron+metsulfuron $25 \mathrm{~g} \mathrm{ha}^{-1}$ at 30 DAS (44.28 g), HW at 15 DAS $\mathrm{fb}$ pre-mix clodinafop+metsulfuron $32 \mathrm{~g} \mathrm{ha}^{-1}$ at 30 DAS (43.89 g) and HW at 15 DAS fbtank-mix isoproturon $250 \mathrm{~g}$ $\mathrm{ha}^{-1}+$ metsulfuron $2 \mathrm{~g} \mathrm{ha}^{-1}$ at 30 DAS (43.65 g). Significantly the lowest test weight was noted with the weedy check (37.16 g). Increased values in these yield attributes might have been on account of the overall improvement in vegetative growth which favourably influenced the tillering, flowering and fruiting and ultimately resulted into increased effective tillers $\mathrm{m}^{-1}$ row length, spikelets spike ${ }^{-1}$, grains spike ${ }^{-1}$ and test weight. The results are parallel with those of Vyavahare (2012); Kumari et al. (2013); Punia et al. (2013); Singh et al. (2015).

The data furnished in Table 2 showed the weed-free check produced significantly the highest grain yield of $3873 \mathrm{~kg} \mathrm{ha}^{-1}$ and straw yield of $5301 \mathrm{~kg} \mathrm{ha}^{-1}$. The next superior treatments in this regard were HW at 15 and 30 DAS, HW at 15 DAS $f b$ premix sulfosulfuron+metsulfuron $25 \mathrm{~g} \mathrm{ha}^{-1}$ at $30 \mathrm{DAS}$, and $\mathrm{HW}$ at 15 DAS $\mathrm{fb}$ pre-mix clodinafop+metsulfuron $32 \mathrm{~g} \mathrm{ha}^{-1}$ at 30 DAS by registering grain yield of 3788,3632 and $3511 \mathrm{~kg} \mathrm{ha}^{-1}$, and straw yield of 5192, 5091 and $4913 \mathrm{~kg} \mathrm{ha}^{-1}$, respectively. These treatments increased seed yield by 95, 91, 83 and $77 \%$, and straw yield by $84,80,77$ and $71 \%$ over the weedy check, respectively. Removal of weeds by hand weeding in initial stage and supplemented with herbicide application suppressed weeds, which in turn provided better weed-free environment

Table 2: Effect of weed management on crop yield and weed parameters

\begin{tabular}{|c|c|c|c|c|c|}
\hline Treatment & $\begin{array}{c}\text { Grain } \\
\text { yield }\left(\mathrm{kg} \mathrm{ha}^{-1}\right)\end{array}$ & $\begin{array}{l}\text { Straw yield } \\
\left(\mathrm{kg} \mathrm{ha}^{-1}\right)\end{array}$ & $\begin{array}{c}\text { Weed } \\
\text { dry weight }\left(\mathrm{kg} \mathrm{ha}^{-1}\right)\end{array}$ & $\begin{array}{c}\text { Weed index } \\
(\%)\end{array}$ & $\begin{array}{l}\text { Weed control } \\
\text { efficiency }(\%)\end{array}$ \\
\hline HW $f b$ metsulfuron & 3298 & 4241 & 580 & 14.85 & 66.99 \\
\hline $\mathrm{HW} f b$ isoproturon & 3129 & 4196 & 613 & 19.21 & 65.11 \\
\hline HW fb clodinafop & 2948 & 3965 & 944 & 23.88 & 46.27 \\
\hline HW fb fenoxaprop & 2141 & 3042 & 1219 & 44.72 & 30.62 \\
\hline HW $f b$ sulfosulfuron+metsulfuron & 3632 & 5091 & 274 & 6.22 & 84.41 \\
\hline HW $f b$ clodinafop+metsulfuron & 3511 & 4913 & 328 & 9.35 & 81.33 \\
\hline $\mathrm{HW} f b$ isoproturon+metsulfuron & 3299 & 4264 & 425 & 14.82 & 75.81 \\
\hline $\mathrm{HW} f b$ isoproturon+fenoxaprop & 2770 & 3826 & 1086 & 28.48 & 38.19 \\
\hline HW $f b$ isoproturon+clodinafop & 3110 & 4011 & 859 & 19.70 & 51.11 \\
\hline HW twice & 3788 & 5192 & 131 & 2.19 & 92.54 \\
\hline Weed-free check & 3873 & 5301 & 30 & 0.00 & 98.29 \\
\hline Weedy check & 1987 & 2881 & 1757 & 48.70 & 0.00 \\
\hline SEm \pm & 138 & 209 & 46 & & \\
\hline $\operatorname{CD}(p=0.05)$ & 404 & 614 & 136 & & \\
\hline
\end{tabular}


to the crop during critical period for growth and development. These results are in conformity with findings of Malik et al. (2012), Kaur et al. (2015), Pal et al. (2015); Singh et al. (2015).

\subsection{Effect on weeds}

The data (Table 2) indicated that the weed-free recorded significantly the lowest dry weight of weeds (30 kg ha-1), followed by HW at 15 and 30 DAS, HW at 15 DAS $f b$ pre-mix sulfosulfuron+metsulfuron $25 \mathrm{~g} \mathrm{ha}^{-1}$ at $30 \mathrm{DAS}$, and $\mathrm{HW}$ at 15 DAS $f b$ pre-mix clodinafop+metsulfuron $32 \mathrm{~g} \mathrm{ha}^{-1}$ at 30 DAS having weed dry weight of 30,131, 274 and $328 \mathrm{~kg} \mathrm{ha}^{-1}, \mathrm{WI}$ of $0.00,2.19,6.22$ and $9.35 \%$, and WCE of 98.29, 92.54, 84.41 and $81.33 \%$, respectively. Efficient control of weeds under these treatments have been reflected in lower dry weight of weeds and evidently showed excellent weed indices. The results corroborate the findings of Yadav et al. (2011); Singh et al. (2013); Tiwari et al. (2015); Chaudhary et al. (2016).

\section{Conclusion}

Effective control of complex weed flora in wheat along with higher yield could be achieved by hand weedingtwice (at 15 and 30 DAS) or HW (at 15 DAS) $\mathrm{fb}$ either pre-mix sulfosulfuron+metsulfuron (25 $\left.\mathrm{g} \mathrm{ha}^{-1}\right)$ or clodinafop+metsulfuron $\left(32 \mathrm{~g} \mathrm{ha}^{-1}\right)$ at 30 DAS.

\section{References}

Chopra, N.K., Chopra, N., Choudhary, D., 2015. Bioefficacy of sole and tank-mix of pinoxaden and clodinafop with carfentrazone and metsulfuron for control of complex weed flora in wheat (Triticum aestivum). Indian Journal of Agronomy 60(1), 104-108.

Chaudhary, D., Singh, P.K., Chopra, N.K., Rana, S.C., 2016. Effect of herbicides and herbicide mixtures on weeds in wheat. Indian Journal of Agricultural Research 50(2), 107-112.

Gill, G.S., Kumar, V., 1969. Weed index a new method for reporting weed control trails. Indian Journal of Agronomy 16(2), 96-98.

Katara, P., Kumar, S., Rana, S.S., Chander, N., 2012. Combination of pinoxaden with other herbicides against complex weed flora in wheat. Indian Journal Weed Science 44(4), 225-230.

Kaur, T., Bhullar, M.S., Walia, U.S., 2015. Bio-efficacy of readymix formulation of clodinafop-propargyl+metsulfuron for control of mixed weed flora in wheat. Indian Journal of Weed Science 47(2), 121-124.

Kondap, S.M., Upadhyay, U.C., 1985. A Practical Manual of
Weed Control. Oxford and IBH Publ. Co., New Delhi.

Kumar, S., Rana, S., Ramesh, S., Chander, N., 2013. Herbicide combinations for broad-spectrum weed control in wheat. Indian Journal Weed Science 45(1), 29-33.

Kumari, A., Kumar, S., Singh, B., Dhaka, A., 2013. Evaluation of herbicides alone and in combination for weed control in wheat. Indian Journal of Weed Science 45(3), 210-213.

Malik, R.S., Yadav, A., Kumari, R., Hasija, R.C., Hooda, V.S., 2012. Suitable herbicides against complex weed flora in wheat. Environment and Ecology 30(3), 717-721.

Pal, S., Sharma, R., Sharma, H.B., Singh, R., Babu, S., 2015. Bio-efficacy and selectivity of different herbicides against weed flora in wheat (Triticum aestivum L.). Indian Journal of Agricultural Sciences 85(5), 655-660.

Pisal, R.R., Sagarka, B.K., 2013. Integrated weed management in wheat with new molecules. Indian Journal of Weed Science 45(1), 25-28.

Punia, S.S., Singh, S., Yadav, D., Hooda, V.S., 2013. Sensitivity and yield performance of wheat varieties as influenced by sulfosulfuron+metsulfuron application. Indian Journal of Weed Science 45(4), 289-290.

Sharma, N., Thakur, N., Chopra, P., Kumar, S., Badiyala, D., 2015. Evaluation of metsulfuron methyl and clodinafop alone and in combination with other herbicides against weeds in wheat (Triticum aestivum L.). Research on Crops 16(3), 447-455.

Singh, A., Kaur, R., Kang, J.S., Singh, G., 2012. Weed dynamics in rice-wheat cropping system. Indian Journal of Agronomy 57(1), 7-16.

Singh, M., Singh, M.K., Singh S.P., Sahu, R., 2015. Herbicide and nitrogen application effects on weeds and yield of wheat. Indian Journal of Weed Science 47(2), 125-130.

Singh, P.K., Singh, A.K., Singh, T.N., 2013. Effect of different herbicides on weed management in wheat (Triticum aestivum L.). Environment and Ecology 31(2), 470-476.

Tiwari, A., Verma, B.K., Dev, J., Kumar, R., 2015. Bioefficacy of clodinafop-propargyl+metsulfuron-methyl against complex weed flora in wheat. Indian Journal of Weed Science 47(4), 422-424.

Vyavahare, S.B., 2012. Weed management in wheat (Triticum aestivum L.). M.Sc. (Agri.) thesis submitted to Mahatma Phule Krishi Vidyapeeth, Rahuri (Maharashtra).

Yadav, M., Punia, S.S., Yadav, A., Jat, R.K., 2011. Efficacy of some ACCase and ALS inhibitor herbicides and their combinations against weeds in wheat (Triticum aestivum L.). Haryana Journal of Agronomy 27(1/2), 18-21. 